\title{
CAVEAT AUCTOR: THE WAR OF THE DICTIONARIES
}

\author{
BY JANICE A. KRAUS
}

Ms. Kraus is the Rare Books Librarian and Exhibitions Coordinator in Special Collections and Archives

MONG the more interesting skirmishes in the history of Ameri-
can lexicography is the episodic "War of the Dictionaries," an im-
broglio which involved Noah Webster ( I 758-I 843 ) and his rival Joseph Emerson Worcester ( 1784 - I 865), along with their publishers and many literary, educational and political figures of the day. During the course of this "war," charges of plagiarism, misrepresentation, booksellers' tricks and calumny were tossed about, leaving everyone involved smeared with their detractors' accusations. Special Collections and Archives has copies of four of the pamphlets issued during this period, publications which are revealing of the kind of defense mounted to combat the opposing side. Three of the four, printed between i 854 - I 860 , have Joseph Emerson Worcester as their protagonist; the fourth, printed in I 860, is a measured anonymous defense of Webster.' The most significant thing about these pamphlets is that they were issued by the respective publishers of Webster's and Worcester's dictionaries, companies with vested interest in sales if not in clarifying or resolving the situation.

It should be noted at the outset that this sort of mudslinging was not

- The four pamphlets in order of publication are:

William Draper Swan. A Reply to Messrs. G. E C. Merriam's Attack Upon the Character of Dr. Worcester and His Dictionaries. Boston: Jenks, Hickling and Swan, 1854.

William Draper Swan. A Gross Literary Fraud Exposed; Relating to the Publication of Worcester's Dictionary in London: Together with Three Appendixes, Including the Answer of S. Converse to an Attack on Him by Messrs. G. E C. Merriam. Boston: Hickling, Swan, and Brown, i 855 .

William Draper Swan. The Critic Criticised, and Worcester Vindicated; Consisting of a Review of an Article in the "Congregationalist," upon the Comparative Merits of Worcester's and Webster's Quarto Dictionaries. Together with a Reply to the Attacks of Messrs. G. E C. Merriam, upon the Character of Dr. Worcester and His Dictionaries. Boston: Swan, Brewer and Tileston, March, I 860.

The Two Dictionaries: or The Reviewer Revierved. A Reply to a Correspondent of the New York World. By Equal Justice. From the New York World, July i 4th, I 860. Springfield, Mass.: G. \& C. Merriam, I 860 . 


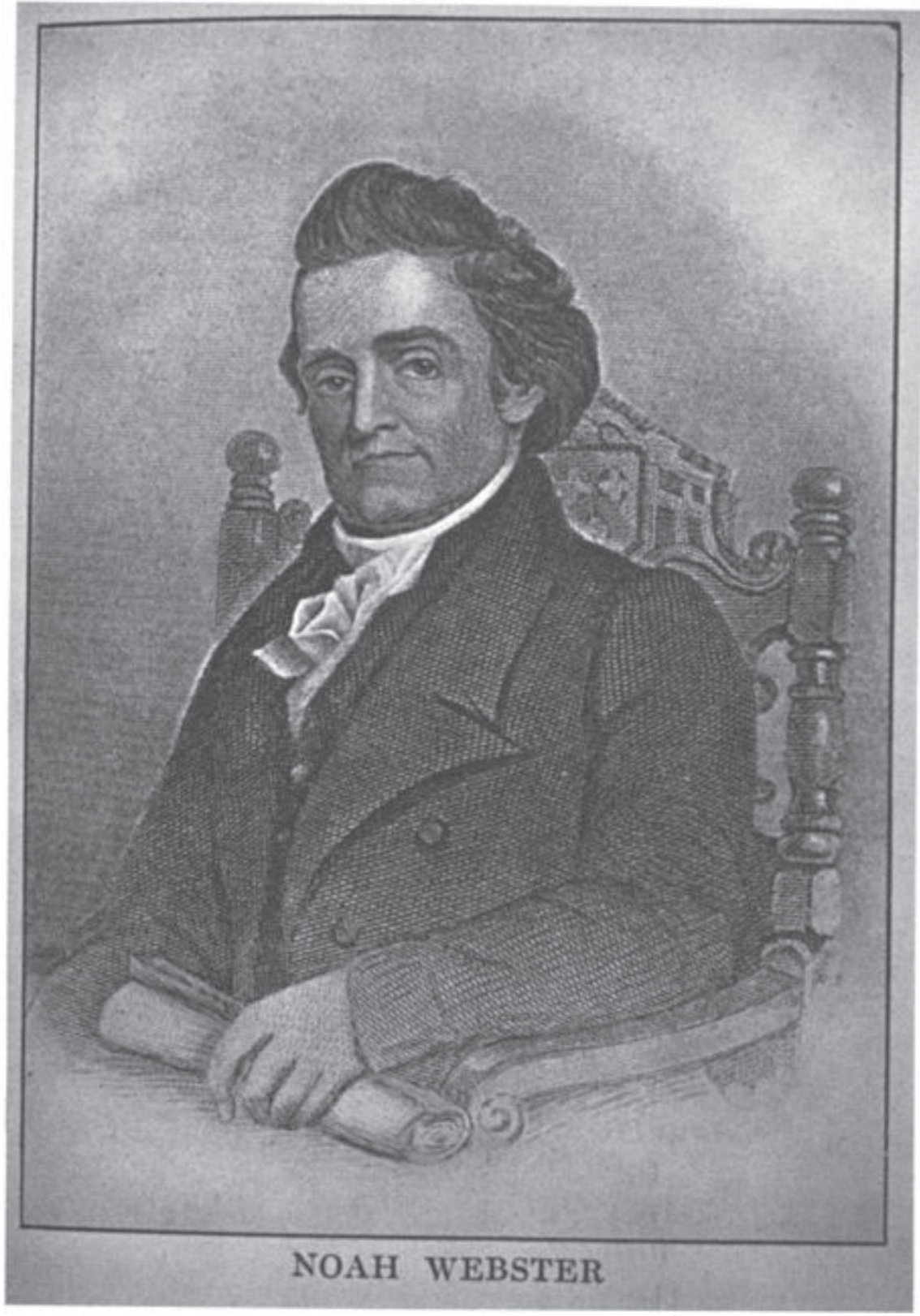


new, either to lexicography in general or to American dictionary-making in particular. Charges of plagiarism had been levelled against many of the great English lexicographers, for example Thomas Cooper, to name an eminent defendant. Futhermore, lexicographers had a tradition of helping themselves generously to the work of their predecessors (as Thomas Elyot had to Calepinus' work) and might or might not give specific credit. ${ }^{2}$ And, often, two competing dictionary-makers or their publishers would vie for dominance of the market: one thinks of the publishers of the Scott-Bailey etymological dictionary rushing out new editions to stave off Johnson's dictionary, or of the battle between the pronouncing dictionaries of Sheridan and Walker which turned on the consideration of which lexicographer was more "English." 3 So disputes among American lexicographers or their publishers were part of the dictionary-making tradition. In this particular case, however, given the relative wealth of letters, newspaper accounts, advertising and pamphlets, one gets a distinct sense of the personalities involved here and it makes for a certain pathos when one remembers that the integrity of the lexicographers themselves was almost the least of it, sales and markets being the real issue.

The four pamphlets in Special Collections and Archives reinforce this market-focussed approach, coupling it with rehabilitory estimations of the compiler's character. William Draper Swan, author of three of the pamphlets, remarked in one that he did not wish ". . . to insinuate that the letter [a defense of Webster] is a malicious fabrication, designed to injure both the moral and literary character of Dr. Worcester, and to affect the sale of his dictionaries . . ."; but that, of course, is precisely what Swan did want to make clear to his readers. The Websterian faction stressed Webster's standing as the première dictionary-maker of America, characterizing Worcester as an unprincipled interloper who had even stooped to cribbing from the master's work. An anonymous letter, originally reproduced in a Merriam publication and included by Swan even states that the writer has ". . . watched the unscrupulous measures with which the publishers of Worcester have pressed their claims to public attention and patronage, striving to defame the fair renown of Webster in their flagitious attempts

${ }^{2}$ DeWitt T. Starnes, Renaissance Dictionaries, English-Latin and Latin-English (Austin, I 954), 86-98 on Cooper; 5 I-54 on Elyot's use of Calepinus.

3 - The English Dictionary From Cawdrey to Johnson, I604-1755 (Chapel Hill, 1946), passim.

${ }^{4}$ Swan, Reply, 5; Swan, Critic Criticised, 54, has a similar sentence. 
to 'fill their pockets' by foisting a comparatively worthless book upon the public."s

One can see, even in the immoderate accusatory style of the nineteenth century, the sempiternal sales pitch at work, the equating of personal honesty with a quality product, exactly the way in which cars are sold today. Endorsements were oftentimes judiciously edited to present a partial statement as the whole truth; once in a while, the endorser, reading such a slanted sentence, would retaliate. For example, "Equal Justice," the anonymous Websterian who compiled one of the pamphlets owned by Special Collections and Archives, quotes a statement which had been circulating widely:

The firm of Harper \& Brothers is almost the only one of note in the United States which has adopted Webster as the standard of orthography. The Appletons, Putnam, and Scribner, of New York; Little \& Brown, Ticknor \& Fields, Crosby $\&$ Nichols, and all the other leading publishing houses of Boston; and Butler and J. B. Lippincott \& $\mathrm{C}_{0}$, of Philadelphia, on the contrary, with enlightened regard for the purity of our language, especially eschew Webster, and have adopted Worcester. ${ }^{6}$

Our pamphleteer went on to quote the gentlemanly disclaimers to this statement, nine in all, from the publishing houses named. Many replied that orthographical considerations were rather left up to individual authors. In any case, the use of such a statement was decried by these firms. As E. H. Butler \& Co. of Philadelphia made known that ". . . the statement that 'we here especially eschewed Webster and adopted Worcester, as the standard of authority in our publications,' is unauthorized and untrue."7 Other replies were less dogmatic, and some, for example, J. B. Lippincott \& Co., were Websterian proponents. But even these firms deferred to their authors and made this known.

More interesting is a letter from Washington Irving of 25 June I 85 I to the New York State Committee on Literature. It deserves to be quoted in full.

Sunnyside, June 25, $185 \mathrm{I}$.

DEAR SIR: Several months since, I received from Messrs. G. \& C. Merriam a copy of their quarto edition of Webster's Dictionary. In acknowledg-

S Swan, Reply, 3-5, quoting letters from G. \& C. Merriam of May, I 853, and from the anonymous writer of April i 3,1853 .

${ }^{6}$ Two Dictionaries, p. [2]. Italics mine. : 7 Ibid. 


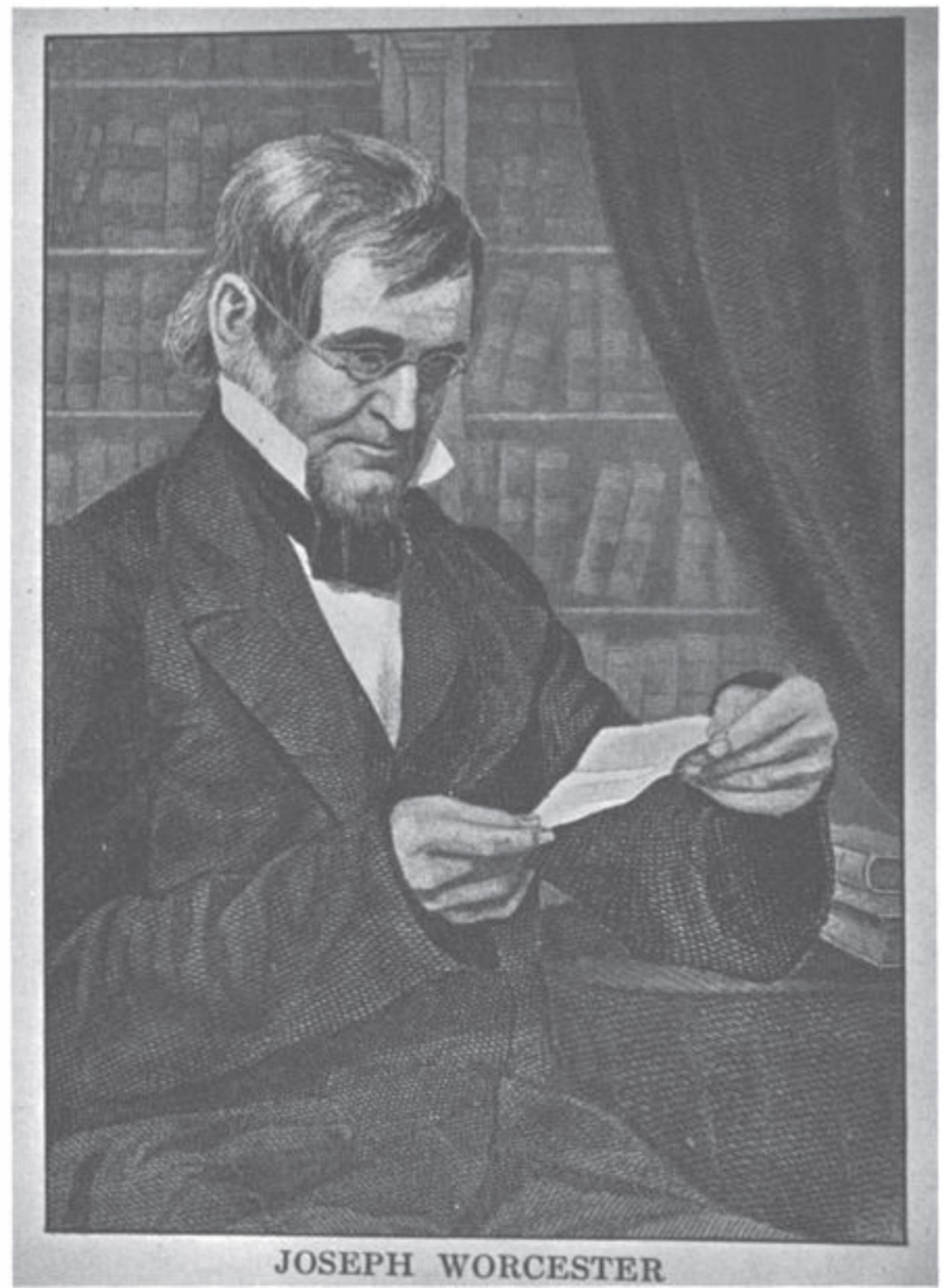


ing the receipt of it, I expressly informed them that I did not make it my standard of orthography, and gave them my reasons for not doing so, and for considering it an unsafe standard for American writers to adopt. At the same time I observed the work had so much merit in many respects that I made it quite a vade mecum.

They had the disingenuousness to extract merely the part of my opinion which I have underlined, and to insert it among their puffs and advertisements, as if I had given a general and unqualified approbation of the work. I have hitherto suffered this bookseller's trick to pass unnoticed; but your letter obliges me to point it out, and to express my decided opinion that Webster's Dictionary is not a work advisable to be introduced 'by authority' into our schools as a standard of orthography.

I am, sir, with great respect,

Your obedient servant,

WASHINGTON IRVING.

To Hon. James W. Beekman,

Chairman of the Senate Committee of Literature. ${ }^{8}$

Irving clearly outlines the problem in a qualified endorsement used for advertising purposes. Although his target was the Merriam Company, it is clear that abuses occurred on both sides. In general, it must be said that both Webster and Worcester were ill-served by their publishers, who used honest disagreement as well as transitory pettiness to serve their own ends.

"The War of the Dictionaries" was fought in two main campaigns: I 834-I843 (the year of Webster's death) and I 846-I 864 (with the unchallenged dominance of Webster's dictionary finally having been achieved and Worcester's death a year later). The first phase was clearly more personal, featuring an exchange of letters between the two protagonists themselves; the second was just as plainly a contest for the market: school, library and home. Although the pamphlets owned by Special Collections and Archives are fairly late, they incorporate material from the first as well as the second phase of the war, most of it being from the Worcesterian side. What is perhaps most interesting is how accurate was the Worcesterian evaluation of the strengths and defects of Webster's work. Indeed, the edition of Webster which finally triumphed, the WebsterMahn edition of I 864, was "one of the best dictionaries ever to appear, but one from which everything really characteristic of Noah Webster him-

${ }^{8}$ Swan, Reply, 30; Swan, Critic Criticised, 7. Cf. Burkett, 229. 
self was deleted."9 Gone were the idiosyncratic spellings and etymologies; ${ }^{\circ 0}$ still-present were the good definitions that had always characterized Webster's dictionaries. And those things, spearheaded by a formidable advertising machine, made possible the "victory" of Webster over Worcester.

That victory was never a certainty during the thirty years preceding Webster-Mahn. Indeed, Webster's whole career as a lexicographer had been marked by hard work, chronic insolvency and the diatribes of his competitors. Early on, his dictionary ( 1828 ) and spellers had been the objects of an anonymous pamphleteering campaign by Lyman Cobb, a New York educator and lexicographer who had sought to derail sales of Webster's dictionaries and other didactic materials in favor of his own. Letters and pamphlets from this campaign were published and widely-distributed just as were those from the later "war." II

The First Phase ( $1834-1843$ )

Noah Webster's I 828 American Dictionary of the English Language had taken him more than twenty years to complete at great cost, both physical and financial. Webster was seventy in I 828 with a lifetime of solid accomplishment behind him, a series of wildly popular readers, grammars and spellers and a name synonymous with American education. The spelling

9 Harold E. Whitehall as quoted in Joseph H. Friend, The Development of American Lexicography 1798-1864 (Mouton, I967), 82. Cf. George Philip Krapp. The English Language in America. Vol. I (New York, 1925), 363.

to Cf. Letters of Noah Webster, edited with an Introduction by Harry R. Warfel (New York, 1953), 460-478. Webster's letter of I 837 to the lexicographer Charles Richardson illustrates some of his etymologies. Though oftentimes fanciful, Webster did know the great etymologists who preceded him such as Menage, Skinner and Du Cange, using their names familiarly throughout this letter.

The evaluation of Webster's orthography and definitions has been consistent almost from the first. Generally speaking, his orthographical innovations, spelling words as they sounded, were unacceptable. Certain changes, such as the omission of the final " $k$ " from words such as public, music, etc. or the omission of the " $u$ " from honor, favor, etc., had also been countenanced by other lexicographers, both in England and America. Cf. remarks in Two Dictionaries, passim; Worcester's statement in Gross Literary Fraud, I4-I 5; Critic Criticised, 6-8; Swan, Reply, 6, 17 passim. Modern discussions in Krapp, 365-366; Eva Mae Burkett, American Dictionaries of the English Language before I86I (Metuchen, N.J., I979), 155-159; Friend, 54-56.

Webster's definitions, on the contrary, were highly praised from the start, as models of succinctness and clarity, even by Worcester. Cf. Swan, Reply, 16-17, 30 (quoting a New York State school report of I $85 \mathrm{I}$ ) and passim; Two Dictionaries, passim. Swan, Critic Criticised, takes a different view. Modern discussions in Burkett, I 59-160; Friend, 43-46.

"Friend, 83. Eva Mae Burkett, I65-1 73; Letters of Noah Webster, 428-43 I. 
books especially had attained a status in America equalled only by the Bible and were used from I 787 to I 900 . The American Dictionary was also hailed as a great work both in America and England, but it suffered in sales because of its high price of $\$ 20$. $^{12}$ Webster's publisher, Sherman Converse of New York, had made a proviso in agreeing to publish the I 828 quarto, which had gone to several publishers previous to him, that he could issue an octavo abridgment at a lower price. Webster, feeling his years and other commitments (one being a study of the Bible), said he himself could not do the revision. Converse, with Webster's agreement, employed Joseph Emerson Worcester of Cambridge to produce the abridgment which appeared in I 829 , oddly without Worcester's name on the title-page. ${ }^{13}$ Worcester, who had worked as a lexicographer prior to this, having published a geographical dictionary in I 8 I 7 (along with other school and didactic texts) and an abridgment of Johnson, ${ }^{14}$ published his own Comprehensive, Pronouncing and Expository Dictionary of the English Language in I 830, a work which became very popular and whose sales began to affect those of Webster. Worcester's dictionary, more conservative in orthography and pronunciation than Webster's, was favored by the Anglophile group in Massachusetts and those of conservative tendencies around the country.

In I 834, an anonymous Websterian began the War of the Dictionaries by writing an inflammatory piece in the Worcester [Mass.] Palladium, accusing Joseph Worcester of having plagiarized Webster's dictionary. As Worcester recounted the incident, "In November, I 834, there appeared in the Worcester Palladium . . . at the instigation, as I was informed, of an agent for Dr. Webster's Dictionaries, an attack upon me, in which the following language was used: 'A gross plagiarism has been committed by Mr. J. E. Worcester on the literary property of Noah Webster, Esq. . . ." Worcester himself denied this in a letter to the Palladium in I 834, pointing out the differences between the two in orthography and pronunciation. ${ }^{\text {Is }}$ Webster himself finally wrote to the Palladium late in 1834 and early in 1835 , noting that he had himself been concerned over the "plagiarism" since $1831 .{ }^{16}$ However, in his letter to Worcester of January 25 , I 835, Webster wrote, "Before I saw, in the Worcester Palladium, a charge against you of committing plagiarism on my Dictionary, I had not given

\footnotetext{
${ }^{12}$ Friend, 34.

13 Gross Literary Frand, "Mr. Converse's Answer," 3-6. Burkett, 174-1 76.

${ }_{14}$ Burkett, 2OI-203.

is Swan, Reply, 9-10.

16 Burkett, 224, quoting Webster's letter of December I I, 1834 .
} 
much attention to your Dictionary." Webster went on to say he had made a quick comparison between the two and believed Worcester had taken certain words from the I 828 quarto without due acknowledgment. ${ }^{17}$

Worcester replied quickly, in a letter of February 6, I 835, that ". . . when an accusation is made, the burden of the proof lies not with the accused, but with the accuser." Worcester then went on to document the English dictionaries (Bailey's, Todd's, Johnson's, Ash's, et al.) in which the disputed words were to be found charging Webster, implicitly, with sloppy scholarship and notes that, in any case, words are in the public domain. Worcester concludes by asking Webster if he ". . . would be so good as to inform me whether the charges against me in the Worcester Palladium were occasioned by any statements made by you, or whether you have ever made, or are now ready to make, any such statements." 18

Sarcastic charges and counter-charges followed in the Palladium and the matter was eventually dropped. ${ }^{\text {ig }}$ The exchange seems the result of the anxieties of a querulous old man, fearful of losing his livelihood to a usurper, who was honestly convinced that his work was completely original with him. In the person of Worcester, Webster saw twenty years of work and money-raising going for naught, with Worcester taking advantage of his [Webster's] work. As Webster wrote to Worcester:

. . My Quarto Dictionary cost me about twenty years of labor and 20,000 dollars. For this labor and such an expense I could never receive remuneration had the market been left open. - How unkind then was it, for you, who had been intrusted with the task of making an abridgment, and had been well rewarded for it, to sit down and introduce some of my improvements into a book of your own compilation, and to put into operation several sets of stereotype plates; for such I am informed is the fact. Now, Sir, rather than treat you in this manner, I would beg my bread. ${ }^{20}$

Thus was the first phase of the "War of the Dictionaries" fought — on a personal level with outward civility. Noah Webster died soon after, in I 843. Shortly thereafter, George and Charles Merriam began publishing Webster's dictionary and their solicitousness for profits was one factor that led to the second phase of the war.

17 Swan, Reply, IO-I I.

${ }^{8}$ Ibid., I I-I 4, with Swan's sarcastic editorial comments interspersed.

19 Burket, 222-226.

${ }^{20}$ Quoted in Burkett, 225-226. Originally published in the Worcester Palladium, February I 8, I 835 . 
The Second Phase (1846-1864)

This second phase was introduced by a circumstance in which Joseph Worcester was guiltless, but which he had to explain away and justify the rest of his life. Worcester had published, in I 846, one of his lexicographical masterpieces, the Universal and Critical Dictionary of the English Language. He duly acknowledged the work of his predecessors, including a gracefully measured tribute to Noah Webster's American Dictionary as "the greatest and most important work on English lexicography, that has appeared since the first publication of Johnson's Dictionary. . . . It is a work of great learning and research, comprising a much more full vocabulary of the language than Johnson's Dictionary . . . but the taste and judgment of the author are not generally esteemed equal to his industry and erudition." ${ }_{21}$ Worcester had been careful to give credit where it was due. In addition, he had made an emphatic disclaimer to borrowings from Webster. ${ }^{22}$

Unfortunately for Worcester, he had no control over the publishing of his volume. It passed from Wilkins, Carter, and Co., to Jenks, Hickling, \& Swan in the United States; previously, Wilkins, Carter, and Co. had authorized a Mr. Brown (of Little, Brown, \& Co.) to negotiate for the publication of Worcester's dictionary in England and the right to publish went to Henry G. Bohn. Bohn apparently altered the title-page and preface plates to make it read as though the dictionary Worcester had published in I 846 had been, as the ersatz title reads ". . . compiled from the materials of Noah Webster, LL.D. By Joseph E. Worcester . . ."23 As Wilkins was forced to admit to Worcester, it had been a slovenly business on all sides. Wilkins, Carter and Little, Brown had not, it appears, gone to much trouble to ascertain the reliability of $\mathrm{Mr}$. Bohn, nor had they demanded a notarized contract. The result was a perpetual embarrassment for Worcester and resurrected the previous charges of plagiarism that had been brought against him in the I 830 .

One might ask where the gain for the London publisher had been in inserting Webster's name on Worcester's title-page. Webster's dictionaries had done well in England, ${ }^{24}$ but Worcester was closer in spirit and

${ }^{21}$ Joseph Emerson Worcester, A Universal and Critical Dictionary of the English Language (Boston, I 846), lxv. Cf. Friend, 9I. Friend, 90-95, discusses the 1846 octavo at some length.

${ }_{22}$ Worcester, Universal and Critical Dictionary, v.

${ }^{23}$ Gross Literary Fraud, quotations from letters of J. E. Worcester to John $\mathrm{H}$. Wilkins, of August 24, I $853,5-7$ in this pamphlet; and a reply from Wilkins to Worcester, of August 31, I $853,8-9$ in the pamphlet. Cf. Burkett, 228.

${ }_{24}$ Burkett, I62. 
methodology to English lexicography than was Webster. ${ }^{25}$ Certainly Worcester's Dictionary of the English Language, published in I 860, was popular in England, receiving the plaudits of the literary figures of the day; he had been known in England, at least since I 83 I, for his scholarly endeavors and there was a painful difference between the treatment Worcester received and that Webster had experienced in England: Webster was virtually ignored during his sojourn there from I $822-\mathrm{I} 825 .{ }^{26}$ The whole affair may have arisen out of a misunderstanding. Burkett quotes a statement Bohn issued regarding the situation in which Bohn claimed that he ". . . understood it [the dictionary] to be an enlarged and Anglicized edition of the Abridgment [of 1829 ] which had previously been compiled by him [Worcester] under the name of Webster." ${ }_{27}$ Clearly, Bohn was the most culpable, or at least negligent, party in this affair; Worcester's publishers and their representatives are not far behind, however, in negligence and incompetence. Wilkins even admitted, in his reply to Worcester, that he had not immediately informed Worcester of the mishap, saying that he and the members of his firm ". . . did not see that any thing could be done to remedy the evil." 28

This incident opened up a Pandora's box of ill-will and opportunism on the part of the rival publishers, with the hapless Worcester caught between them. It was at this point and during the next several years that William Draper Swan, Worcester's publisher, compiled three of the pamphlets owned by Special Collections, primarily from letters and documents sent him by Worcester, interweaving these with offending passages from pamphlets issued by the Merriams. ${ }^{29}$ Everything since the 1830 os was reproduced in these pamphlets, including Worcester's always-dignified rejoinders, testimonials for both sides from college presidents, schoolteachers and headmasters, quotations from anonymous pamphlets and, of course, correspondence from the respective publishers.

These pamphlets are obviously tendentious, designed to sway the public, beginning with the purposive titles. The intent of the three Worces-

25 Burkett, 205, 2 I0.

${ }^{26}$ Burkett, 21 2, 216-217, 208, I 42-145.

27 Burkett, 232; brackets mine.

${ }^{28}$ Gross Literary Fraud, letter from John H. Wilkins to J. E. Worcester of August 3 I, 1853 , p. 9 in this pamphlet.

${ }_{29}$ William Draper Swan (I 809-1 864) had himself been an educator in Boston before becoming a bookseller and publisher. He was undoubtedly part of the conservative circle which supported Worcester's lexicographical ideology. Cf. Appleton's Cyclopaedia of American Biography, edited by James Grant Wilson and John Fiske (New York, I 889), Vol. VI, 4, for brief biographical details. 
terian pamphlets was to vindicate Worcester as a man of integrity and scholarship. To accomplish this, testimonials were sought from the principals involved from the 183 os onward. One caveat: the passage of time had without doubt altered or hardened feelings about Webster, particularly on the part of Sherman Converse, the publisher of his I 828 quarto. The letter of Converse to Worcester of 3 I August I 853 , reveals some bitterness toward Webster, specifying his lack of graciousness and adequate concern over proper remuneration to himself. ${ }^{30}$

In a long letter of April I 854 to Worcester, Converse wrote that

They [the Merriams] are in possession of wealth which, but for misfortune, would have been mine. And rather than misrepresent and abuse me, it would better become them to send me a copy of the Dictionary, handsomely bound, accompanied by a check for a liberal amount on their bankers, with a kind note requesting my acceptance of both, in acknowledgment of riches derived from the large Dictionary, for which, primarily, they have been so greatly indebted to my efforts and misfortunes..$^{3}$

That notwithstanding, the issue of whether Worcester had been directly employed by Webster or by Converse, who held the copyright, and what rights Worcester had subsequent to his work is mixed. Both sides had different interpretations of the facts, obviously to their advantage, but in truth the issues may never have been clearly articulated.

By I 853 Converse recalled that he had himself hired Dr. Worcester to do the abridgment, a recollection at odds with that of the Merriams who stated that Worcester was directly in Webster's employ. ${ }^{32}$ Webster's Preface in the I 829 octavo says that, since Webster himself was unable to do the work, ". . . the work has, therefore, been committed, for this purpose, to Mr. J. E. Worcester, of Cambridge, Massachusetts, who had strictly adhered to the general principles laid down for his direction by the author." 33 However, the 1829 octavo abridgment was not consistent with the I 828 quarto: it included many new words and had a more conservative tone, ${ }^{34}$ as is evident by the addition of Walker's Key to pronunciation,

${ }^{30}$ Quoted in Swan, Reply, 7 .

${ }^{31}$ Quoted in Swan, Gross Literary Fraud, IO-I I (second group).

${ }^{32}$ Swan, Reply, 7.

${ }^{33}$ An American Dictionary of the English Language . . by Noah Webster, LL.D. . . To Which are Added, A Synopsis of Words . . . and Walker's Key. . . (New York, I829), [iii] . Cf. Burkett, I74.

${ }^{34}$ Burkett, 2I 3. Cf. An American Dictionary, [iii]-v. For the responsibility of members of Webster's own family in this fiasco, see Burkett, 175 -1 76. 
which Webster himself never would have countenanced. Clearly, Worcester had had a fairly free hand in revising the 1829 edition. And with that the stage had been set for the misunderstandings that were to follow.

Webster never forgave anyone connected with the I 829 abridgment. Burkett quotes a letter written by Webster shortly before his death in which he still lamented the 1829 issue. A man of unquestioned principle, Webster regretted the abridgment ". . . not only as it regards profits, but as it regards its usefulness." He went on to enumerate what he saw as its shortcomings, among them that ". . . the definitions are abridged, and in some cases are defective . . . I found also that none of the corrections and improvements in the body of the work, which is stereotyped, are introduced . . . in a few instances the publishers or owners have deviated purposely from my decision, so that the work must not be considered mine, though most of it is taken from mine." 35 Ironically, in later issues of the I 829 octavo, edited by Chancey A. Goodrich, Worcester's contribution was never even mentioned. ${ }^{36}$ In Worcester's defense, it would have been hard to draw the line between work on one dictionary, the 1829 octavo and the subsequent I 830 Comprehensive which Worcester had been engaged in at the same time. And, as far as methodology went, the two were so similar that there was not much of a line to draw. Worcester's research seems, at least from the testimonials one reads, 37 to have been better than Webster's. Swan's Reply cites several resolutions from bodies such as legislatures, school boards and eminent educators, such as Horace Mann, as proof of the general acceptability of Worcester over Webster, but the situation was more mixed than that. People seemed to recognize the merits each had, Webster in definitions, Worcester in orthography and pronunciation, no matter how the publishers of each tried to cloud the issue..$^{8}$ The publishers regularly appended to their pamphlets a string of testimonials from booksellers and colleagues, ${ }^{39}$ all giving the impression that those "in the know"

35 Burkett, I 75-1 76, quoting Webster's letter of April I I, I 843 to his son-in-law William Chauncey Fowler.

${ }^{6}$ Swan, Critic Criticised, 5.

37 Friend, 92-95; Burkett, 2 I6-2 I 8, citing Carlyle, Thackeray, Dickens et al.

$3^{8}$ Swan, Reply, I 7, 22 passim; Swan, Critic Criticised, passim. Cf. Swan, The Critic Criticised vs. The Two Dictionaries. Each pamphlet tried to persuade the reader of the superiority of the definitions in Worcester and Webster, respectively; one of the criteria for excellence seems to have been length. The dictionaries in question are the Dictionary of the English Language (Boston, I 860) of Worcester and the I 859 Merriam Webster.

39 Two Dictionaries, [2]; Swan, Critic, [2], 68-72. 


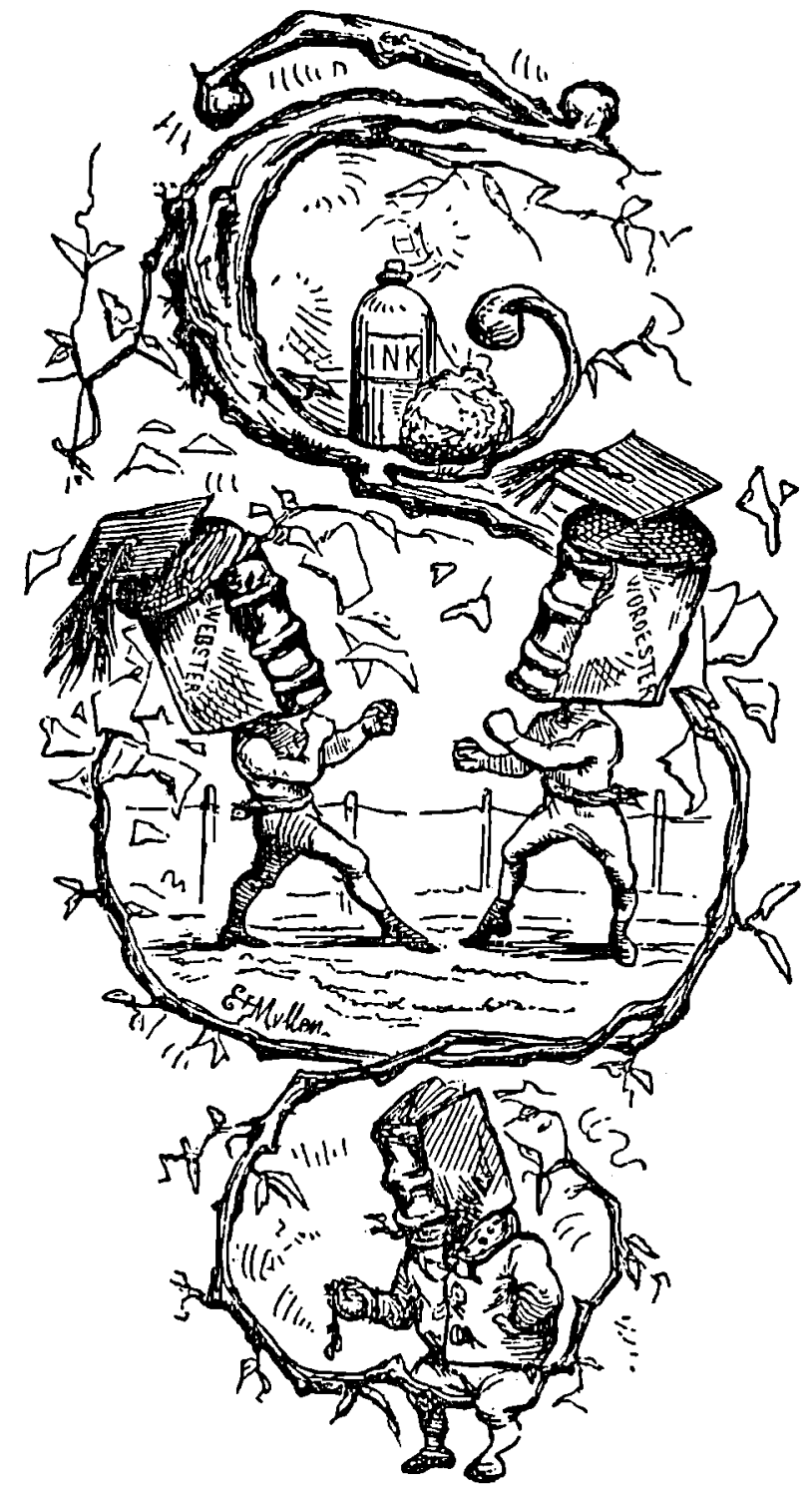

"Sporting Intelligence: The Battle of the Dictionaries" from a cartoon in Vanity Fair, March 10, 1860. 
selected one or the other and bidding the dependent public to do likewise. The evidence, though, is in favor of a fairly even race between the two dictionaries.

The evidence of the four pamphlets, printed between I 854 and I 860 , indicates a hard-fought battle being waged. Worcester's orthographical and orthoepical refinements, definitions and learning are vigorously defended, with abundant illustration in The Critic Criticised, and Worcester Vindicated; lest the overweening language of the pamphlet seem out of place, remember that this was a reply to Websterian attacks which used the same immoderate language. Between the verbiage of the two camps they virtually beat their protagonists to death. One of the few cadenced treatments of the subject comes from the anonymous "Equal Justice," a Websterian, but a fairly dispassionate one. His pamphlet was published in I 860 by which time, as he says, "The public, in general, are tired of the dispute." $4 \circ \mathrm{Also}$ by this time the editions of Webster had been undergoing, for nearly twenty years, a process of attenuation, becoming less a manifestation of their founder than a product of the mainstream. This was in great measure due to the success of the Merriam Company which had set Webster's dictionaries on a new course.

The Merriams established an editorial board for the dictionary and set about reviving Webster's reputation, a program which included aggressive advertising (among their slogans was the famous "GET THE BEST"), initiation of assaults and prompt response to the Worcesterian camp, and the solicitation of endorsements already referred to. ${ }^{4 \mathrm{I}}$ By I 860 , the year "Equal Justice" wrote, the two dictionaries were very close to one another. "Equal Justice," though a Websterian, had the grace to write, "In some respects, Worcester and Webster supplement each other, and every literary man who can, will choose to have the two." ${ }_{42}$ Even this early, the still-usual estimations held: Worcester for spelling and pronunciation, Webster for definitions. By I 853 , with the publication of the philologist C.A.F. Mahn's edition of Webster, Worcester's editions were losing out. Dictionary-making, now a task for a committee, was an overwhelming Juggernaut that a one-man operation such as Worcester's could not combat. ${ }^{43}$

${ }_{40}$ Two Dictionaries, II .

${ }^{41}$ Robert Keith Leavitt. Noah's Ark, New England Yankees and the Endless Quest. A Short History of the Original Webster Dictionaries, with Particular Reference to their First Hundred Years as Publications of the G. and C. Merriam Company. . . (Springfield, Mass.), 45-50.

${ }^{42}$ Two Dictionaries, 15.

${ }^{43}$ Leavitt, 56-67. 
Such was the "War of the Dictionaries," a tawdry episode in which two scholarly, diligent men of fundamentally different views on language became enmeshed in the tangle of businessmen's opportunism. As George Philip Krapp has written, concerning the advertising and selling of the dictionaries, this ". . . subject is a chapter in the history of American business methods which must be left to the student of morals." 44

${ }^{44}$ Krapp, Vol. I, 372. 